\title{
Hyperbilirubinemia; Current Causes, Causal Risk Factors and Endpoints
}

\author{
Hiperbilirubinemi; Güncel Nedenleri, Nedene Yönelik Risk Faktörleri ve Sonlanımlar
}

\author{
Mehtap ŞIMŞEK, Gönül ŞENGÖZ, Filiz PEHLIVANOĞLU \\ Haseki Training and Research Hospital, Clinics of Infectious Diseases and Clinical Microbiology, Istanbul, Turkey
}

\begin{abstract}
Objectives: Hyperbilirubinemia has a broad spectrum of causes ranging from benign lifethreatening. Classification of hyperbilirubinemia as prehepatic, hepatic and posthepatic promotes detecting its etiology.

Materials and Methods: In this study, we analyzed the diagnoses, etiological risk factors and endpoints in 60 patients with hyperbilirubinemia. Inclusion criteria included moderate-bad general condition, enzyme levels $>2000 \mathrm{U} / \mathrm{L}$, bilirubin levels $>5 \mathrm{mg} / \mathrm{dL}$, impaired coagulation parameters and fever and rashes. Age, gender, etiology, contamination patterns, physical examination, laboratory findings and prognosis were analyzed retrospectively.

Results: The diagnoses of the diseases based on their incidence were hepatitis $B(n=34)$, hepatitis $A(n=12)$, activation of chronic HBV infection $(n=5)$, autoimmune hepatitis ( $n=2)$, malaria $(n=2)$, hepatitis $E(n=1)$, leptospirosis $(n=1)$ and liver abscess $(n=1)$. Mean age and female/male distribution ratio for viral hepatitis were 33 and $1 / 2$, respectively. When risk factors were questioned; risk factors could not be identified in $69 \%$ of patients with viral hepatitis. Use of municipal water was found in history of $17 \%$ cases with hepatitis A whereas history of suspected sexual contact and dental treatment were found in $26 \%$ and $17 \%$ of patients with hepatitis B. Intrafamilial contamination was found in seven cases. Bicytopenia and monocytosis were observed in $15 \%$ and $84 \%$ of subjects. The mean bilirubin value was $16 \mathrm{mg} /$ $\mathrm{dL}$ with the highest value of $44.6 \mathrm{mg} / \mathrm{dL}$. The highest ALT were averagely $3170 \mathrm{U} / \mathrm{L}$ and $2891 \mathrm{U} / \mathrm{L}$ in patients with hepatitis $\mathrm{A}$ and $\mathrm{B}$, respectively. Two patients became exitus while one patient was referred to an external center for transplantation. The diagnoses in those three patients were hepatitis $B$ and autoimmune hepatitis. Conclusion: Although, joundice is related with many diseases, in Turkey, it is most commonly associated with viral hepatitis. (Viral Hepatitis Journal 2014; 20(3): 87-90) Key words: Hyperbilirubinemia, acute viral hepatitis, liver transplantation
\end{abstract}

Conflict of interest: The authors reported no conflict of interest related to this article.

\section{ÖZET}

Amaç: Erişkinde hiperbilirubinemi; benign nedenlerden, hayatı tehdit edici nedenlere kadar geniş yelpazededir. Prehepatik, hepatik ve posthepatik olarak hiperbilirubinemiyi sınıflandırmak etyolojinin bulunmasını kolaylaştırmaktadır. Iki yıllık dönemde sarılıkla izlenen 60 hastanın tanıları, etyolojiye yönelik risk faktörleri ve sonlanımları reprospektif olarak irdelenmiş̧tir.

Gereç ve Yöntemler: Sarılıkla başvuran hastalarda, hastaneye yatma kriterleri olarak: genel durumun orta-kötü olması, karaciğer enzimlerinin $>2000 \mathrm{U} / \mathrm{L}$ olması, biluribin değerlerinin $>5 \mathrm{mg} / \mathrm{dL}$ olması, koagülasyon parametrelerinin bozulmuş olması, ateş ve döküntü varlığı kabul edilmiştir. Hastaların yaş, cinsiyet, etiyoloji, bulaş yolları, fizik muayene, laboratuvar bulguları ve prognozları retrospektif olarak incelenmiştir.

Bulgular: Hastaların tanıları akut viral hepatit $B(n=34)$, akut viral hepatit $A(n=12)$, kronik HBV enfeksiyonu aktivasyonu $(n=5)$, otoimmun hepatit $(n=2)$, sitma $(n=2)$, akut viral hepatit $E(n=1)$, leptospiroz ( $n=1$ ) ve karaciğer apsesidir $(n=1)$. A ve $B$ viral hepatiti için yaş ortalaması ve kadın erkek dağılımı sırasıyla 33 ve yaklaşık $1 / 2$ 'dir. Hastalarda risk faktörleri sorgulandığında viral hepatitler için \%69 oranında risk faktörü tanımlanamamıştır. A viral hepatitinde $\% 17$ olguda şebeke suyu kullanımı, B viral hepatitinde $\% 26$ şüpheli cinsel temas, \%8 diş tedavisi öyküsü saptanmıştır. Aile içi bulaş yedi olguda mevcuttur. Hastaların $\% 15$ inde bisitopeni, \%84'ünde monositoz varlığı saptanmıştır. En yüksek biluribin değeri $44,6 \mathrm{mg} / \mathrm{dL}$, ortalama 16 $\mathrm{mg} / \mathrm{dL}$ 'dir. Hastaların takipleri boyunca saptanan en yüksek ALT düzeyleri A ve B hepatitinde sırasiyla ortalama $3170 \mathrm{U} / \mathrm{L}$ (571-5304) ve ortalama $2891 \mathrm{U} / \mathrm{L}$ 'dir (14005525). İki hasta kaybedilirken bir hasta transplant için dış merkeze gönderilmiştir. Bu üç hastanın tanıları akut viral hepatit B ve otoimmun hepatittir.

Sonuç: Sarılık birçok hastalıkla ilişkili olarak saptansa da ülkemizde hala en sık viral hepatitlerle ilişkili olarak karşımıza çıkmaktadır. (Viral Hepatit Dergisi 2014; 20(3): 87-90)

Anahtar kelimeler: Hiperbilirubinemi, akut viral hepatit, karaciğer transplantasyonu

Çıkar çatışması: Yazarlar bu makale ile ilgili olarak herhangi bir çıkar çatışması bildirmemişlerdir.

\section{Introduction}

Jaundice (icterus) is a clinical manifestation involving accumulation of bilirubin in the mucous membranes, skin, sclerae and the extracellular fluid in case of hyperbilirubinemia. Bilirubin is formed by a breakdown product of heme rings resulting usually from erythrocyte metabolism $(1,2,3,4)$. Hyperbilirubinemia has a very broad spectrum of causes ranging from benign factors to lifethreatening conditions. The classification of hyperbilirubinemia as prehepatic, hepatic and posthepatic may help find out its etiology (1). Increased serum unconjugated (indirect) bilirubin results from prehepatic causes of jaundice including hemolysis and hematoma resorption. Unconjugated and/or conjugated hyperbilirubinemia 
is monitored in the intrahepatic pathologies. Direct bilirubin levels are increased by alcohol, toxic reactions, infectious hepatitis and autoimmune diseases (1). Even though jaundice is not a common complaint in adults, nevertheless, it may be a sign of a very serious pathology (1). In this study, we analyzed the diagnostic data distributions and demographic characteristics, and outcomes of patients who attended with symptoms of jaundice in the infectious diseases Clinic at Haseki Training and Research Hospital in 2013.

\section{Materials and Methods}

This study included 60 patients who applied with the complaint of jaundice and were hospitalized in our clinic. The inclusion criteria included moderate-poor general condition, liver enzymes $>2000$ $\mathrm{U} / \mathrm{L}$, biluribin values $>5 \mathrm{mg} / \mathrm{dL}$, impaired coagulation parameters, presence of fever and eruptions. The diagnoses, age, gender, physical examination, risk factors, laboratory findings, and endpoints were analyzed retrospectively. The patients were diagnosed based on the clinical findings, biochemical and microbiological tests.

The presence of positive serological markers have been diagnosed with acute viral hepatitis. Negative viral markers and antinuclear antibody (ANA) positivity were searched for the diagnosis of autoimmune hepatitis. Observed microscopically thin and thick smears for the diagnosis of malaria parasites are considered. Leptospirosis was diagnosed with Leptospira IgM. Liver abscess was identified radiologically.

\section{Results}

When the diagnoses of the patients were analyzed; $85 \%$ were found to be associated with viral agents. The remaining patients were found to have autoimmune hepatitis $(n=4)$, malaria $(n=2)$, leptospirosis $(n=1)$ and liver abscess $(n=1)$ (Table 1).

The mean age of the patients with viral Hepatitis $A$ and $B$ and the female-male ratio were 33 years and $1 / 2$, respectively. When the patients were surveyed for risk factors, the risk factors could not be identified in $69 \%$ of subjects with viral hepatitis. Use of municipal water was found to be responsible for viral hepatitis A in $17 \%$ of cases while viral hepatitis B was associated with suspicious sexual contact and medical history of dental treatment in $25.6 \%$ and $7.6 \%$ of cases, respectively. When family history was questioned for the etiology of viral hepatitis, 3 subjects were found to have several family members with or with a recent history of acute hepatitis $A$. The presence of positive inactive HBsAg was encountered in the families of 4 subjects with medical history of acute viral hepatitis B. Bicytopenia and monocytosis were detected in $15 \%$ and $84 \%$ of patients, respectively. The mean bilirubin value was $16 \mathrm{mg} / \mathrm{dL}$ with the highest level of $44.6 \mathrm{mg} / \mathrm{dL}$. Mean ALT levels in patients with hepatitis A and B were $3170 \mathrm{U} / \mathrm{L}$ (571-5304) and $2891 \mathrm{U} / \mathrm{L}$ (1400-5525), respectively. Time to diagnosis was 24 hours for malaria while it was two days for viral hepatitis. This time interval for the other diseases prolonged up to seven days due to laboratory facilities. Two patients became exitus while one patient was referred to an external medical center. These three patients were diagnosed with acute viral hepatitis B and autoimmune hepatitis. The patient with autoimmune hepatitis was transferred to the clinic of internal medicine while the other two patients were discharged because their clinical and laboratory findings improved (Table 2).

Although jaundice is associated with many diseases, it is most commonly observed in cases of viral hepatitis. In the comparison, hepatitis $A$ is found in earlier ages with female-male ratio of.equal whereas hepatitis $B$ is encountered in older ages and, 3-fold more frequently in women than in men (Table 3 ).

\section{Discussion}

Although hyperbilirubinemia is a very common finding in clinical practice and is a symptom of many diseases, there is only limited data related with its etiology, diagnostic methods and prognosis in the literature.

There are several methods for the differential diagnosis of hyperbilirubinemia; etiological factors may be generally detected by applying a few simple and low-cost tests as a result of a good anamnesis. In some cases, prolonged hospital stays requiring many costly investigations may be needed (5).

In this study, we analyzed the etiology of hyperbilirubinemia and the indication for admission in patients who applied to our clinic of infectious diseases and were followed up. The most common factor was found to be acute viral hepatitis $(n=34,56.6 \%)$. Altıntaş et al. have evaluated patients with total bilirubin levels above $5 \mathrm{mg} / \mathrm{dL}$ within a 3-month period and found that the most common causes of serious jaundice were malignancy and viral hepatitis (48\%) (5). In studies conducted on adult patients with acute hepatitis, acute viral hepatitis $B$ was found to be the most prevalent condition followed by viral hepatitis $A$ and $C$. However, in some studies, hepatitis $A$ has been shown to be more frequent $(6,7)$. Also in our study, viral hepatitis $B$ ranked first and was followed by viral hepatitis $A$. Viral hepatitis $C$ and hepatitis $D$ accompanying viral hepatitis $B$ have not been observed in a 1-year period. Targeting to reduce the incidence of hepatitis $B$ by vaccination programmes is the essential aspect of the struggle against hepatitis $B$ virus. In our country, the incidence of acute viral hepatitis type $B$ is between 0 and $25 \%$ depending on the regions (6). Hepatitis $A$ infection, as an important health problem in the undeveloped and developing countries, is closely associated with hygienic conditions and socioeconomic levels. It is more commonly observed within the first years of life in the undeveloped countries whereas it is found in adolescents and young adults in the developing and developed countries $(8,9)$. In Turkey, the

\begin{tabular}{|l|l|l|}
\hline Table 1. The distribution of the patients & $\mathrm{n}$ & $\%$ \\
\hline Diagnosis & 34 & 57 \\
\hline Acute viral hepatitis B & 12 & 20 \\
\hline Acute viral hepatitis A & 1 & 1.6 \\
\hline Acute viral hepatitis E & 5 & 8 \\
\hline Acute exacerbation of chronic viral hepatitis B & 4 & 7 \\
\hline Autoimmune hepatitis & 2 & 3 \\
\hline Malaria & 1 & 1.6 \\
\hline Liver abscess & 1 & 1.6 \\
\hline Leptospirosis & & \\
\hline
\end{tabular}




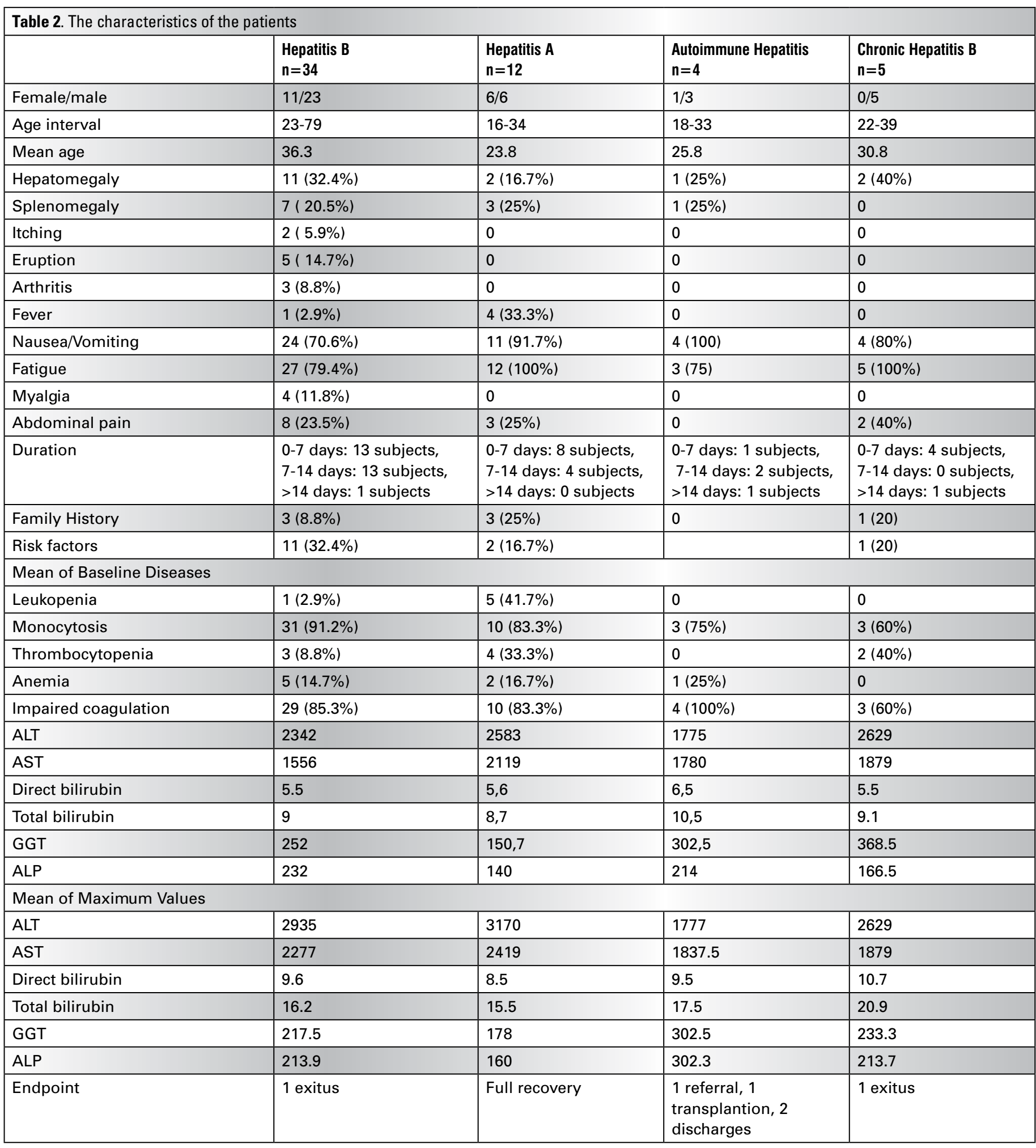

Table 3. The comparison between the patients diagnosed Hepatitis $A$ and $B$

\begin{tabular}{|c|c|c|c|c|c|c|c|c|c|c|c|c|}
\hline & $F / M$ & Age & HM & SM & Fatigue & Nausea & Fever & PLT & ALT & AST & D bilirubin & $\mathrm{T}$ bilirubin \\
\hline Hepatitis A & 1 & 24 & 17 & 25 & 100 & 92 & 33 & 33 & 2580 & 2140 & 6 & 9 \\
\hline Hepatitis B & 0,4 & 36 & 33 & 18 & 82 & 72 & 3 & 13 & 2040 & 1350 & 5 & 8 \\
\hline
\end{tabular}


seroprevalence of acute viral hepatitis varies depending on geographic regions, age and socioeconomic status. Turkey is in the region of moderate endemicity with the prevalence data ranging between $8 \%$ and $88 \%(10)$. In our study, the mean age of the patients with viral hepatitis A was 23.8 years (range: 16-34) and a female-male ratio was $1 / 1$. Of these patients; $25 \%$ $(n=3)$ had several family members with or with a recent history of hepatitis A. Hepatitis A virus is transmitted by fecal-oral route. Hepatitis $A$ can be transmitted from person to person by failure to comply with hygiene rules (8). Control of working in the food industry and hand washing habits in daily life in society is important in preventing the spread of hepatitis $A(6,8)$. In our study, no risk factor was identified in two patients with acute viral hepatitis; one of them had a history of using municipal water.

In studies on hyperbilirubinemia, the characteristics of patients also determine distribution of the diagnosis as well as clinic that they have applied. Malignancies rank first in studies conducted in clinics of internal medicine and, especially in surgery clinics where elder patients are followed up. This study that was conducted to investigate whether there was a decline in the incidence of hepatitis due to vaccination programme which continued for approximately 15 years. We found that the prevalence of hepatitis was still high and that the target of reducing the prevalence has not been achieved yet. The diagnosis of 60 patients with jaundice who were admitted 10 years ago in oue Clinic were analyzed and distribution of the diagnosis were found very similar.

\section{References}

1. Roche SP, Kobos R. Jaundice in the adult patient. Am Fam Physician. 2004; 69(2): 299-304.

2. Kruger D. The assessment of jaundice in adults: Tests, imaging, differential diagnosis. JAAPA. 2011; 24(6): 44-49.

3. Gaze, R, Carvalho DM, Santoro-Lopes G, Tura LF. From hepatic diseases and jaundice to viral hepatitis: the configuration of a kaleidoscope. Rev Saude Publica. 2013; 47(1): 116-122.

4. Mıstık R. Sarılıklı hastaya yaklaşım. Ed. Wilke Topçu A, Söyletir G, Doğanay M. Enfeksiyon Hastalıkları ve Mikrobiyolojisi, Sistemlere Göre Enfeksiyonlar, 3. Baskı, Istanbul, Nobel Tıp Kitapevleri, 2008; s:1141.

5. Altıntaş $E$, Tombak $A$, Tellioğlu B. Ciddi hiperbilirübinemi nedenleri, tanı ve sağaltımı. Akademik Gastroentoloji Dergisi. 2010; 9(1): 2-7.

6. Yöntem B, Hakyemez IN, Aksu A, Şimşek F, Kantürk A, Yıldırmak MT. Akut Hepatitli 596 Erişkin Olgunun Retrospektif Değerlendirilmesi. Vir Hep Derg. 2012; 18(3): 87-90.

7. Tekin Koruk S, Gürsoy B, Koruk I, Yıldız Zeyrek F, Unutmaz G, Karaağaç L. Viral hepatit olgularının değerlendirilmesi. Vir Hep Derg. 2006; 11(3): 132-137.

8. Franco E, Meleleo C, Serino L, Sorbara D, Zaratti L. Hepatitis A: epidemiology and prevention in developing countries. World $\mathrm{J}$ Hepatol. 2012; 4(3): 68-73.

9. Mackinney-Novelo I, Barahona-Garrido J, Castillo-Albarran F, Santiago-Hernandez JJ, Méndez-Sánchez N, Uribe M, ChávezTapia N. Clinical course and management of acute hepatitis A infection in adults. Ann Hepatol. 2012; 11(5): 652-657.

10. Yoldaş Ö, Bulut A, Altındiş M. Hepatit A Enfeksiyonlarında Güncel Yaklaşım. Vir Hep Derg. 2012; 18(3): 81-86. 